\title{
Decision Making Processes in Counter-Terrorism Operations in Israel
}

\author{
Amnon Sofrin \\ Department of International Relations, The Hebrew University of Jerusalem, Jerusalem, Israel \\ Email address: \\ Amnon.sofrin@mail.huji.ac.il

\section{To cite this article:} \\ Amnon Sofrin. Decision Making Processes in Counter-Terrorism Operations in Israel. Journal of Political Science and International \\ Relations. Vol. 4, No. 3, 2021, pp. 112-124. doi: 10.11648/j.jpsir.20210403.16
}

Received: August 23, 2021; Accepted: September 4, 2021; Published: September 11, 2021

\begin{abstract}
Israel is fighting terrorism from its very early days. The terror acts are characterized by carrying out lethal attack on Israeli residents and/ or the abduction of civilians / soldiers in order to free Palestinians imprisoned in Israeli jail. During the years Israel's counterinsurgency doctrine was shaped based on two main cornerstones - Moshe Dayan's doctrine of reprisal actions on terror attacks, formulated in the early 1950s, and the "Rabin Doctrine" on dealing with abducted Israelis. This article will analyze the processes of decision- making in Israel when fighting the two main forms of terror acts. After reviewing the main decision - making model a new decision- making model will be presented - the Two-Group Decision Making Model that will be demonstrated through analysis of four case studies: two cases of terror attack that Israel reacted by a military reprisal operation and two cases in which Israelis were abducted and the decision- makers had to choose to surrender to the terrorists demands or to launch a military rescue operation. The main conclusions of this article are that most of the decision- making process is made within a very small and intimate group headed by the leader and in most cases the Israeli decision - makers prefer to carry out a military operation on negotiations or any other course of action.
\end{abstract}

Keywords: Counterinsurgency, Israel, Rescue Operations, Reprisal Actions, Decision Making

\section{Introduction}

This article will focus on the process of decision - making in a crisis situation, when the decision makers have to decide how to react within a short time, under a lot of pressure and usually, amid great ambiguity. In this article I will analyze how the Two-Group Decision Making Model is implemented in decisions regarding a crisis scenario such as a mass terror attack on Israel or the abduction of Israeli civilians or soldiers.

After reviewing the current literature and Israel's policy in such cases, I will analyze four case studies. Two will demonstrate the dilemmas facing decision makers in incidences of the abduction of Israelis, to surrender to the terrorists demands or to launch a military rescue operation: the abduction of Israeli passengers to Entebbe, Uganda in 1976, and the 1994 abduction of Corporal Nachshon Wachsman by Hamas terrorists to a secret location that was ultimately exposed by Israel.

The other two cases deal with reprisal operations Operation "Father of Wisdom" (1978's Operation Litani) was launched following a lethal terrorist attack on Israel's coastal road, and Operation "Defensive Shield" was launched in 2002 following a wave of deadly terror attacks in Israel, with one of the most horrific taking place on Passover Eve.

The article will examine the alternatives explored by the decision makers, why a military operation is preferred and selected, who leads this course of action and what is the dynamics of the decision- making process.

\section{Method}

\subsection{Models of Foreign Policy Decision - Making}

Foreign Policy Decision Making (FPDM) refers to the choices made by individuals, groups or coalitions that affect the state's activities in the international arena. Such decisions are usually characterized by high levels of uncertainty, risk and cost [66].

There are two main approaches to FPDM research: The rational model assumes that a state, acting as a "lone player," will try to maximize gains and cut losses while navigating the 
anarchic international system. The rational decision maker choses from a set of alternatives the alternative that maximizes utility (Robinson and Snyder 1965, 437; Rosati and Scott 1993, 268). The main model of the rational approach is the Expected Utility Model [50, 54].

The second approach is the cognitive model, which assumes that decision makers have limited ability to process information, and that instead of making efforts to gather relevant information, they will choose the first acceptable, "good enough" alternative. The decision makers choose an alternative from a "narrow" set of alternatives, weigh it, and if the alternative doesn't meet the requirements, they move on to the next alternative until they find the one that is most satisfying [54, 45, 52].

The main models of the cognitive approach are the Prospect Theory [50, 43, 72], the Poliheuristic Model [53, 55, 59], and the Organizational Politics Model [13, 1].

In a scenario that is perceived by the decision makers as a crisis, they have to make fatal decisions within the restrains of high uncertainty and time pressure [69, 7].

The decision makers have to weigh and consider the available alternatives that will provide the best solution to the crisis. These alternatives may include diplomatic, economic or military action $[65,48]$.

When the leader has to decide on a certain issue, he consults with the "inner circle" that includes his advisors and people very close to him; this group, "the small group" is, in fact, the group that makes the decision $[30,54,73,36]$.

The decision - making group can be placed on a continuum of decision-making dynamics, from "completely cohesive" [groupthink] to "completely fragmented" [polythink]) [56]. In groupthink, the group making the decision "seeks consensus at the expense of exploring a variety of alternatives...The group exhibits self-censorship and feelings of invulnerability and does not tolerate contrary viewpoints as it seeks to consolidate its unanimity" [40]. Polythink is a group dynamic whereby different members in a decisionmaking unit espouse a plurality of opinions and offer divergent policy prescriptions, even dissent, which can result in intra-group conflict and a fragmented, disjointed decisionmaking process. Members of the polythink decision making unit, by virtue of their disparate worldviews, institutional affiliations, and decision-making styles, typically have deep disagreements over the same decision problem [56].

\subsection{The Two-Group Decision Making Model}

In a situation that is perceived as a crisis, the critical decision unit is the "small group" that typically consists of a leader and very few advisors. We refer to this as the Decision Design Group (DDG). The group explores different alternatives and designs its preferred course of action. Within this group we may find sometimes an "inner team" that includes the leader and 1-2 close advisers that actually designs the preferred course of action and bring it to the DDG for discussion. Once the group has agreed on a certain course of action, it is presented to a larger team - a cabinet, or government - for approval. This group is called the Decision Approval Group (DAG). The dynamics of the DDG (i.e., groupthink or polythink), the dynamics of the discussion within the DAG, and the overall dynamics between these groups shape the ultimate decision [70].

When the Decision Design Group (DDG) agrees on its preferred course of action, the leader and his (or her) advisors will make any effort to gain support from the "large group" (DAG). Members of the DDG will try to convince DAG members to support the DDG's decision. They may also choose not to expose all of the information, but only that information that supports their preferred course of action [70].

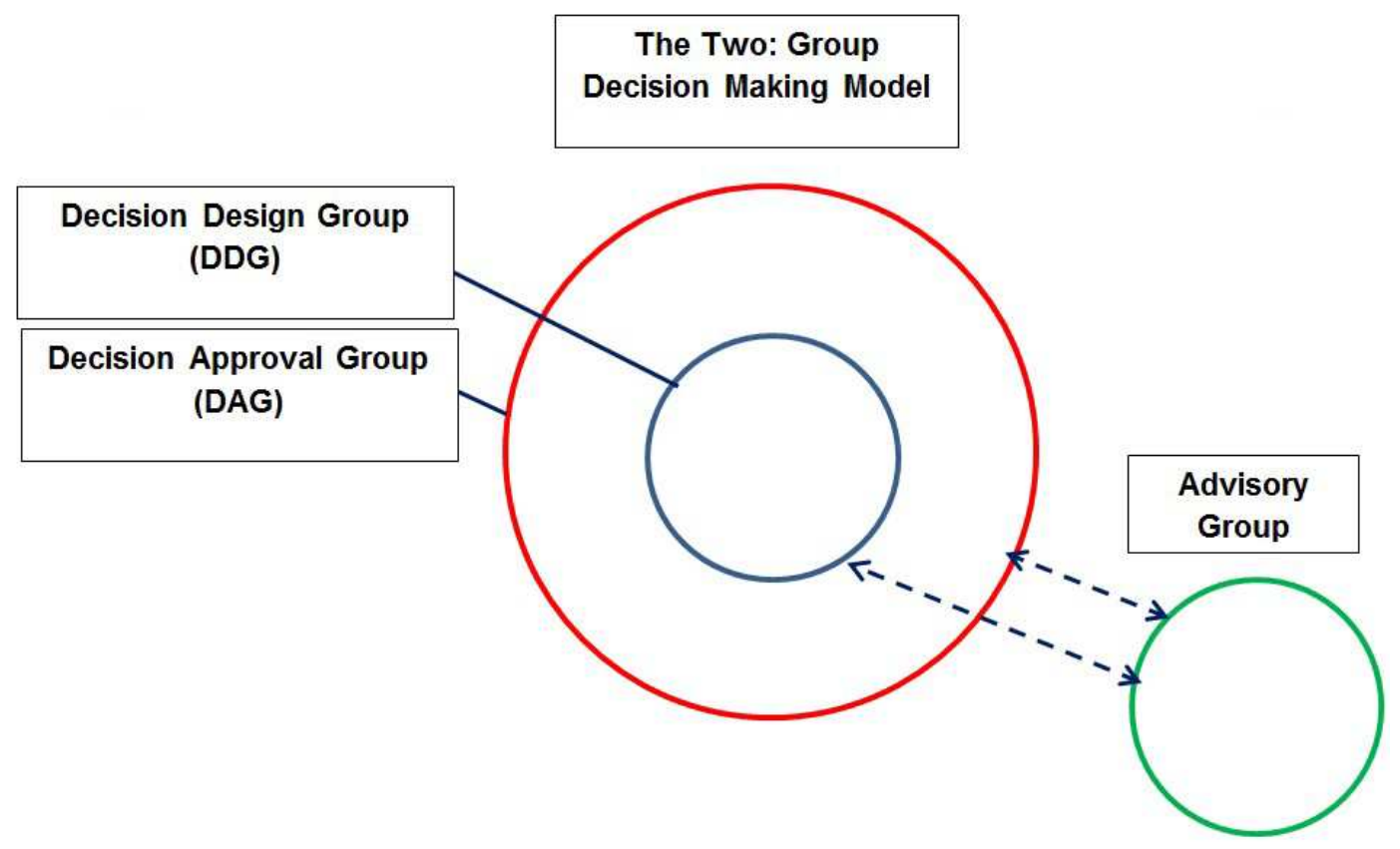

Figure 1. The Two- Group decision- making model. 
There are several possibilities for intergroup interaction. When the dynamics of the discussions in the DDG are those of groupthink and the discussion in the "large group" (DAG) is also characteristic of groupthink, the course of action designed by the DDG will be adopted "as is" (e.g., the decisions of the Israeli government to engage in the First and Second Lebanon Wars). When the dynamics in both groups are those of Polythink, the leader will make every effort to "impose" his preferred course of action and the decision will reflect his choice (e.g., the debate in Israel regarding whether to attack the missile launchers in western Iraq during the First Gulf War in 1991).

\subsection{Israeli Policy on Counterinsurgency (COIN)}

In western military circles, the issue of coping with non-state adversaries has been defined around the concept of counterinsurgency (COIN) (Khal 2007, 472; Moyer 2009, 2). Israel has been dealing with terrorist threats since the early years of its independence, when the terror groups fighting Israel carried out attacks on residents, in some cases taking hostages.

In these early days of the state, Arab gangs infiltrated Israel for the prospect of good plunder, which often also resulted in the loss of life (Drory 2005, 65). Moshe Dayan, the IDF Chief of Staff from 1953 to 1958, adopted a policy of commando operations, deep raids behind enemy lines, in order to compel the Arab governments to take responsibility for stopping the gangs (ibid). Dayan defined this "doctrine", as follows: "We do not have the means to prevent the murders of [Israeli] workers in orchards or of families sleeping in their beds at night. What we can do is set a very high price for our blood, so high that no Arab locality, Arab army or Arab government will want to pay it" (Dayan 1955).

Israeli forces conducted raids into Egypt during the early 1950 s in response to attacks by the Cairo-backed Palestinian "Fedayeen" (Hughes 2011, 54) and into Jordan to try to force Jordan to seal its side of the border and prevent the attacks on Israel (Ben Dor, Pedatzur, and Hasisi 2003, 2).

After the Yom Kippur War in 1973, Israel faced a new challenge - terrorist groups infiltrated into Israel from Lebanon and abducted hostages. In a situation like this, the decision makers must decide how to free the hostages without succumbing to the terrorists' demands or causing the death of the hostages, without diminishing the government's legitimacy (Hermann and Hermann 1998, 211-212).

There are two schools of thought regarding abductions: The hardline approach believes that fulfillment of the terrorists' demands will be interpreted as surrender, encouraging others to carry out such attacks because of their proven effectiveness [71]. The other school of thought is the flexible approach, which is characterized by "the will to make deals with terrorists to obtain the release of hostages and bring a quick end to any terrorist attack" [71].

The view of Israeli Prime Minister Yitzhak Rabin, whose first term was from 1974 to 1977, was that Israel should prefer military rescue operations to release hostages captured by terrorist groups, even if the chances of securing their successful release was small, and even if there was the possibility of casualties among the hostages or rescue team. However, if a rescue operation was not feasible, Israel would be willing to negotiate and respond to at least some of the terrorists' demands in order to secure the release of the hostages. This came to be known as the "Rabin Doctrine" [26].

The terrorist organizations quickly understood the Israeli policy and changed their methods accordingly: they abducted Israeli civilians and soldiers and took them either to a distant place or to a secret hiding place in order to prevent Israel from carrying out a rescue operation. In the absence of the ability to implement the Rabin Doctrine, Israel found itself negotiating the release of hostages [63].

\subsection{We'll Analyze Two Case Studies in Which Israel's Decision-Makers Faced the Dilemma of How to Handle a Situation of Israeli's Abducted Persons}

\subsubsection{The Abduction of Israeli Passengers to Entebbe, Uganda in 1976 and the Decision on a Rescue Operation}

On Sunday, June 27, 1976, an Air France airplane originating in Lod, Israel on its way to Paris was hijacked several minutes after taking off from a stopover in Athens. On board the airplane were 160 passengers, 103 of whom were Israeli residents. The hijackers were members of an extremist Palestinian organization. The airplane was ultimately landed in Entebbe, Uganda and the passengers were brought into the airport's old terminal building. The hijackers demanded the release of fifty-two Palestinians held in prisons in Israel, West Germany, Kenya and France [52].

As soon as the Israeli government was notified of the hijacking, Prime Minister Rabin appointed and led a special small team of five ministers to handle the problem $[22,60$, 64, 52].

The Chief of Staff, the director of Military Intelligence and the director of the Mossad also attended in the team's discussions. This group of officials in fact made up the Decision Design Group (DDG) that explored all the alternatives and debated the preferred course of action.

The group's discussions were typical of the dynamics of Polythink. Prime Minister Rabin, with the support of most of the members of the DDG, favored negotiating with the terrorists as long as there was no reasonable military solution. Rabin, who had a great deal of military experience, saw the complexity of a military rescue operation in such circumstances, considering the distance, the lack of information, and other factors [78, 80]. Rabin knew that a failed operation with many casualties would result in the loss of Israel's deterrence and would also end his own political career (Williamson 1976, 26).

Defense Minister Peres did not see the complexity of a military operation and the huge risks involved, and continued to press the IDF brass to design a reasonable military rescue operation (Eran 2019; Gazit 2019). Peres supported negotiations only insofar as they bought more time to come up with a military plan with an acceptable level of risk (Herzog 1996, 336). 


\section{The Positions of Main Players - Polythink - Polythink}

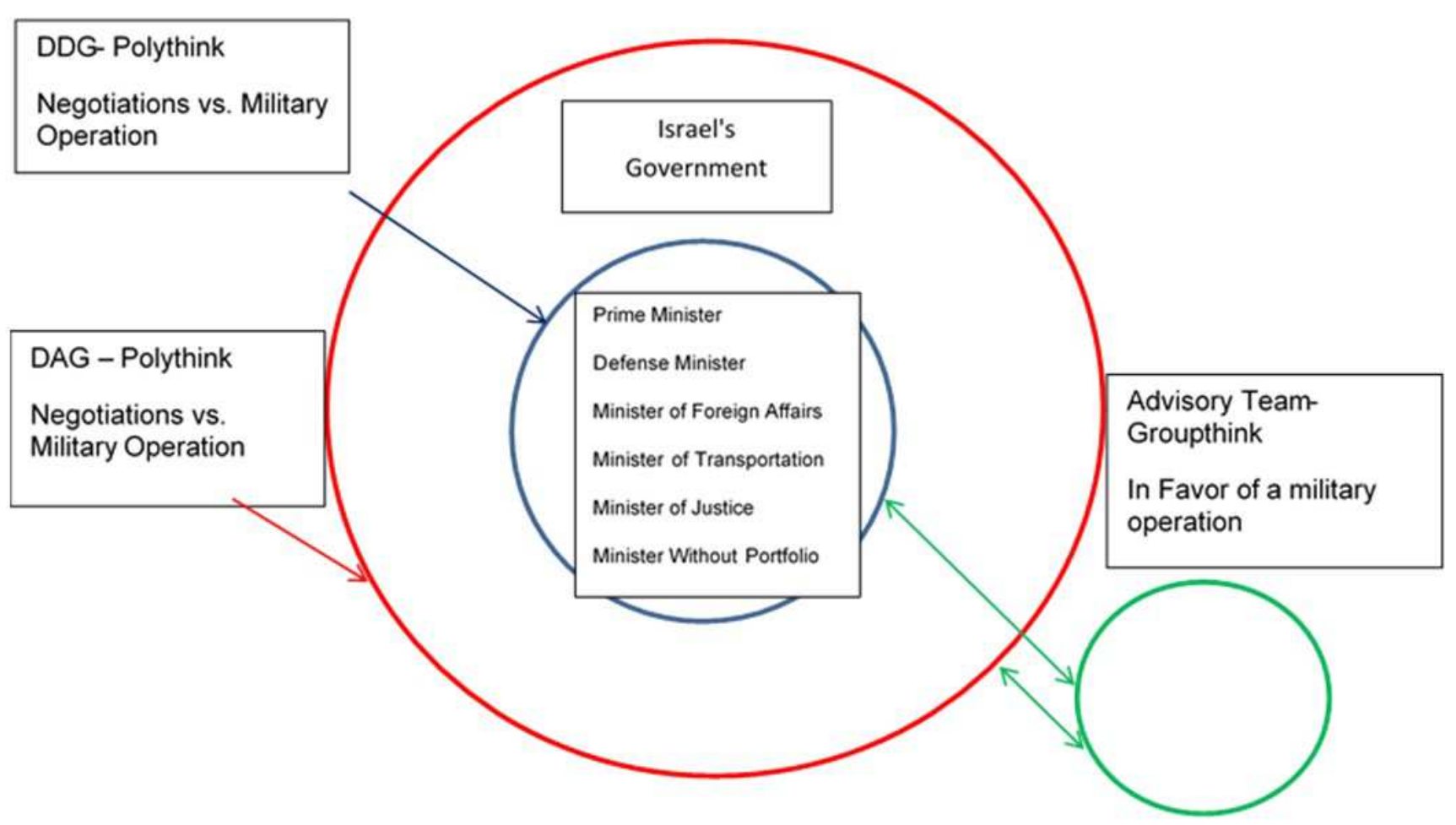

Figure 2. Decision- making process on the Entebbe case.

On July 1, Prime Minister Rabin asked the government for a quick decision approving the release of the imprisoned terrorists whose freedom had been demanded by the terrorists in exchange for the release of the hostages (Herzog 1996, 337).

The government unanimously approved the prime minister's proposal (Rabin and Goldstein 1979, 527). Following the government's decision to begin negotiating with the terrorists, the latter extended the ultimatum until Sunday, July 4 (Herzog 1996, 528; Maoz 1981, 689).

The IDF continued planning. On Friday, July 2 at noon, Defense Minister Peres and the Chief of Staff presented Prime Minister Rabin a military rescue plan that Rabin thought was reasonable (Rabin and Goldstein 1979, 528).

On the Saturday morning of July 3, additional information came in. The Chief of Staff and the Director of Military Intelligence with Defense Minister Peres presented the Prime Minister with the information, and recommended that he approve the rescue operation (Gazit 2019).

The prime minister approved the operation, but told them he wanted to get the government's (the Decision Approval Group-DAG) approval and asked that the government convene at noon (Eran 2019). Before the meeting, Rabin told the Director General of the Prime Minister's office, Amos Eran, that he had decided to launch the operation and that there was a good chance that the operation would succeed. He asked Eran to prepare a letter of resignation of the prime minister to be submitted to the president in the event that the operation failed. When Eran asked him how he would define failure, Rabin's answer was "a lot of casualties - twenty-five people or more ..." (Eran 2019).

On Saturday noon Israel's government convened to approve the rescue operation. IDF Chief of Staff Gur presented the operational rescue plan, and emphasized that "If it is not a total surprise it may lead to disaster..."[28].

Following a lengthy discussion, the rescue operation was unanimously approved $[28,60,64]$. The rescue team landed at the Entebbe airport at approximately $11 \mathrm{pm}$ on July 4 . The operation lasted about 55 minutes; all of the terrorists were killed. The commander of the elite commando unit, Lt. Col. Yoni Netanyahu, was killed, and another soldier was badly injured. Three of the hostages were also killed during the operation, and an older woman, Dora Bloch, who was hospitalized in a hospital in Uganda on the evening before the operation was launched, was later killed at Idi Amin's order. All of the other hostages were released and returned to Israel on board one of the air force's airplanes [60].

\subsubsection{Main Insights}

The abduction of Israeli air passengers to Uganda, about 4000 kilometers from Israel, coupled with the lack of available information, posed a huge dilemma for Israeli decision makers. They had to decide whether to surrender to the terrorists' demands, contradicting government policy and 
risking the encouragement of further terrorism against the Israeli people [74], or try to rescue the hostages in a military operation.

The crisis was handled mainly within the Decision Design Group, which explored all of the options and made attempts to apply international pressure on Ugandan President Amin to help free the hostages [11].

The DDG's discussions were characterized by the dynamics of Polythink; This led to parallel actions - a decision to begin negotiations with the terrorists while working on a viable military rescue plan [19].

The Decision Approval Group - the Israeli government was called in for meetings on two occasions. The first was on July 1 , to approve the decision made by the DDG to begin negotiations with the terrorists, a discussion that also bore the dynamics of Polythink; a few of the ministers objected, but there was no other available option. The second time the DAG gathered was on Saturday, July 4 to approve the military operation. This meeting bore a groupthink dynamic, and the operation was approved.

\subsubsection{The Abduction of Cpl. Nachshon Wachsman and the Rescue Operation}

In September 1993, Israel and the Palestinians signed the Oslo Accords in Washington, D.C., which determined that control of Gaza and Jericho was to be handed over to the Palestinian Authority (PA). The Palestinian leader, Yasser Arafat, and his headquarters were located in Gaza.

On October 9, 1994, Hamas terrorists abducted Cpl. Nachshon Wachsman [49]. Two days after Wachsman's abduction, the kidnappers released a videotape from Gaza, trying to mislead Israel that he was held in Gaza, showing a masked terrorist holding Wachsman's ID and personal rifle, claiming that they were holding Wachsman and demanding that Israel release Hamas leader Sheikh Ahmed Yassin and other Hamas's members imprisoned in Israel in exchange for his release. The kidnapper demanded that Israel free the prisoners by Friday evening, October 14 [76].

Israeli Prime Minister Rabin believed that Wachsman was being held in Gaza, which was now controlled by the Palestinian Authority. Rabin appealed to Arafat, telling him that he held him responsible for ensuring Wachsman's safe return, and emphasized that if Arafat failed to do so, it would cast his authority over the territories he controlled in great doubt.

Rabin had explored the alternatives with the Decision Design Group, which included the minister of foreign affairs, the IDF chief of staff and the head of the Shin Bet. The Decision Approval Group, the "Cabinet" included seven ministers, headed by Prime Minister Rabin [85].

Since there was no information about where Wachsman was being held, and because time was running short, the DAG unanimously decided to begin negotiations with the kidnappers, stipulating that if a viable military rescue operation was to be found as a result of new information, it would take priority over negotiations with the terrorists (Rubinstein 2019). Both groups (the DDG and the DAG) acted on the dynamics of groupthink; the group's members believed that Israel should not surrender to the terrorists' demands and should act militarily if such a thing was feasible [86].

The prime minister ordered IDF Chief of Staff Lt. Gen. Ehud Barak to prepare for a rescue operation in Gaza should information come in regarding Wachsman's holding place [76].

In the early morning of Friday, October 14, a combined intelligence effort revealed that Wachsman was being held in the village of Bir Naballah in Judea and Samaria [61, 49, $76,5]$.

Meeting was called in the prime minister's office. Shin Bet officials recommended the planning of a rescue operation [61].

Rabin consulted with Chief of Staff Barak and the commanding general of the IDF's Central Command and decided, on his own, without convening the Decision Approval Group, to launch a military rescue operation (Ben Israel 2006, 5). Later on, Rabin explained that he had acted on his own because he was concerned about leaks, and the success of the rescue operation was hinged on it being a complete surprise to the terrorists [76].

On Friday evening, the rescue teams carried out a raid on the house where Wachsman was being held. As the operation began, Wachsman was murdered by his captors. An officer, Captain Nir Poraz, was killed during the short battle, and another seven soldiers were wounded. The four Hamas terrorists were also killed.

\subsubsection{Main Insights}

In the case of the abduction of Nachshon Wachsman, the "Rabin Doctrine" was implemented one more time: as long as the Israeli government did not know where the abducted soldier was being held, and as long there was no option of a military rescue operation, the government should make every effort to release Wachsman in other ways - such as by placing enormous pressure, including by international entities, on Arafat to engage Hamas and try to find out where the abducted soldier was.

The discussions within the DDG and the DAG throughout that week bore the dynamics of groupthink: both groups agreed that if a military rescue option were to arise, it would become the prioritized course of action [86, 85]. When Wachsman's hiding place was exposed, Rabin acted in an unusual manner - he decided on his own, without consulting or updating the other cabinet members, and without getting their approval for the operation. In this case the decision was made within the "inner circle" only without the approval of the DDG and the DAG. Rabin said his decision had to be done this way since time was running short (the ultimatum's deadline was 9:00 PM), and because the terrorists were not aware of the fact that they had been exposed, so a military operation would take them completely by surprise and he was therefore wary of any leaks [85].

The decision-making process in this case can be described as follows: 


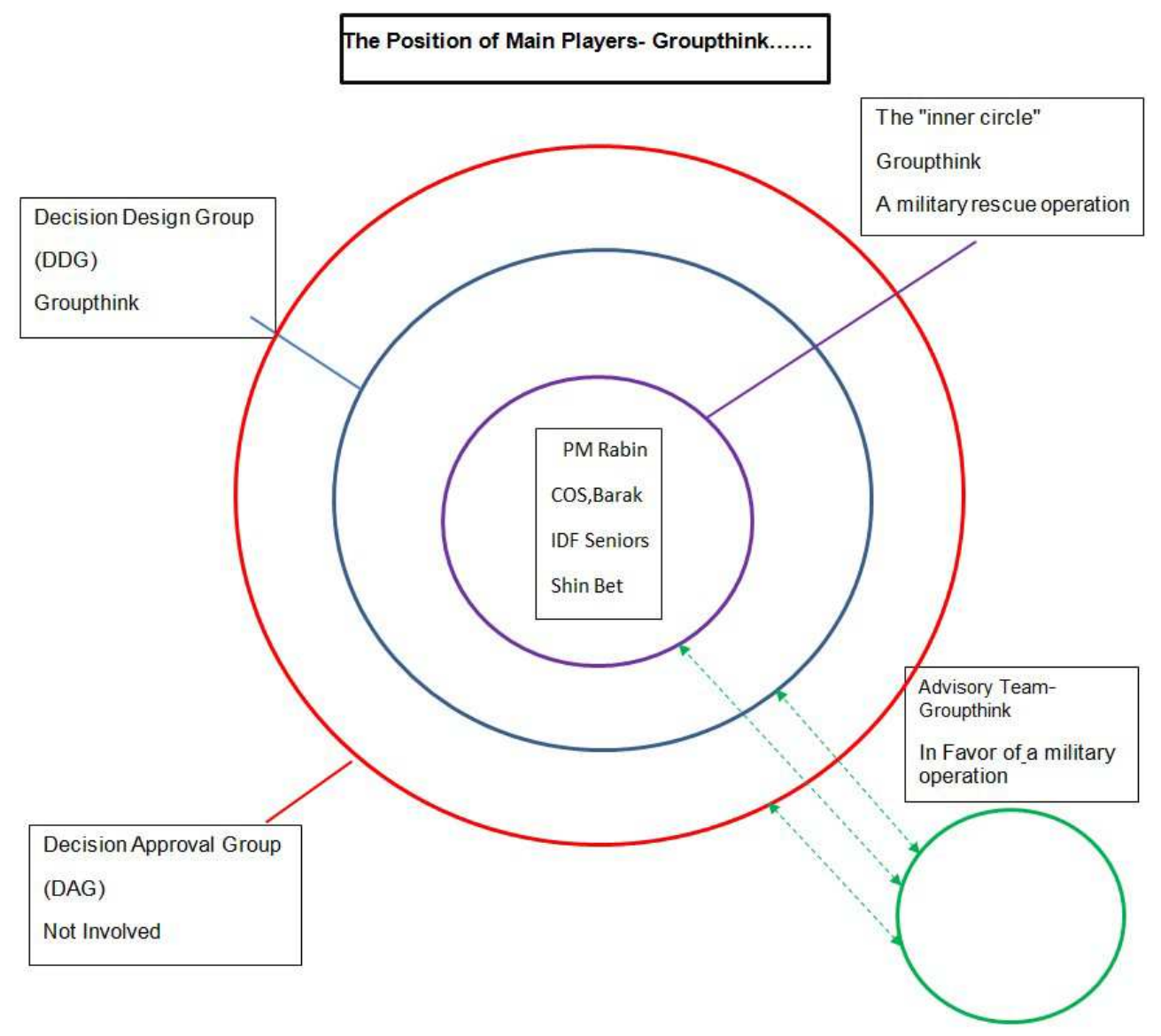

Figure 3. Decision - making process on Wachsman's case.

\subsection{We Will Now Turn to Another Area of Counter - Terrorism - Reprisal Operations}

As mentioned, this concept was shaped by Lt. Gen. Moshe Dayan, the IDF Chief of Staff in the early 1950s. In 1972, Israel carried out two focused raids on terrorist camps and infrastructure in southern Lebanon. The goals of these operations were to restore Israeli deterrence, compel the terrorists to stop their belligerent behavior for as long as possible, and disrupt the preparatory stages of terrorist attacks - the planning of the attacks, the training of the terrorists, the preparation of the explosives and weapons, and other support activities [25].

On the issue of how Israeli decision- makers decide on which case to react with a military reprisal operation, what are the aims and to what extent other alternatives are explored we'll analyze two case studies of extreme lethal terrorists' attacks were carried on Israeli residents and how the decision- makers considered their way to react.

\subsubsection{Operation "Father of Wisdom" ("Litani”) - 1978}

On March 11, 1978, a group of Palestinians landed on the Israeli coast about thirty kilometers south of Haifa, hijacked a bus full of weekend travelers and drove it to the suburbs of Tel Aviv, where the ensuing stand-off with Israeli security forces resulted in thirty-four Israelis killed and another seventy-four wounded. This terrorist attack sent a wave of outrage throughout Israel [23].

Immediately after the battle was over, IDF Chief of Staff Lt. General Gur called for an urgent meeting, during which he ordered the IDF Northern Command to prepare "a very broad military operation in south Lebanon which will focus on taking over all of the terrorists' positions close to the Israeli border" [24].

That evening, the prime minister called for a meeting of the "security cabinet", in effect the Decision Design Group.

There was fury in the air at the cabinet meeting. According to Maj. Gen. Gazit, the Director of Military Intelligence, "When an atrocity like the coastal road massacre occurs, the Israeli government sees red. It is inconceivable that it won't react" [8].

The chief of staff presented the DDG with a plan to advance some ten kilometers northwards to destroy the Palestinian Liberation Organization (PLO) camps and installations [24, 8].

The discussions held in the DDG bore the dynamics of groupthink - all of the group members supported a military reprisal operation, with some of the ministers even claiming that Israel must hold the most dominant positions in south Lebanon within a ten-kilometer strip from the international border [17].

On Sunday, March 12, the Chief of Staff presented the military plan to the government, the Decision Approval 
Group (DAG). He presented two options: to carry out a raid, destroy all of the PLO camps and installations and then return back home, or to stay there until some agreement was reached. Lt. Gen. Gur emphasized that this was a risky situation; an Israeli military presence in a ten-kilometer-deep enclave in Lebanon would not stop rockets from being launched on Israeli residents, and Israeli soldiers in south
Lebanon would be exposed to attacks [24].

The discussions within the Israeli government, the DAG, were also characterized in the dynamics of groupthink, the ministers agreed that a forceful response was needed. Since the dynamics of both groups were of groupthink, none of the ministers objected to the proposed operation or raised the question about how it would end [24].

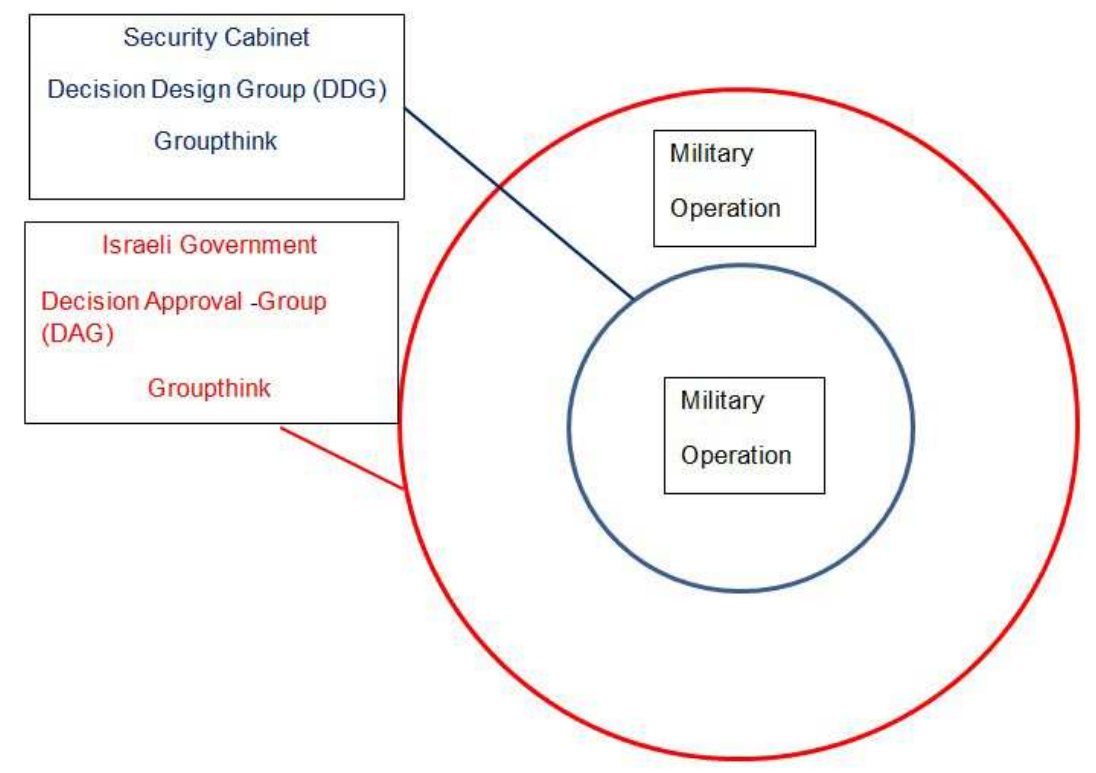

Figure 4. Decision- making process on the first phase of operation "Litani".

Operation "Father of Wisdom," or "Litani," was launched on March 14, 1978. Phase A of the operation was completed within one day; the IDF captured territory in south Lebanon at a depth of six to ten kilometers [24].

On March 15, the chief of staff and the defense minister reported to the Knesset Foreign Affairs and Defense Committee with regards to how the operation was advancing. The defense minister told the members of Knesset that the operation had been launched "to clear this infested area once and for all" and added that Israel would keep control of the area until it received assurances that the PLO could no longer strike at Israel (Keesing's Contemporary Archives 1979). He emphasized that "one of the things we are going to do is remove the terrorists north of the Litani River" [24]. Chief of Staff Gur was caught completely by surprise, as this course of action had never been discussed or approved [24].

Following Israel's invasion, the US called upon the United Nations Security Council to pass a resolution calling for Israel's immediate withdrawal from south Lebanon and the deployment of UN forces there [24].

On March 17, three days after the operation's launch, the defense minister initiated a discussion with Prime Minister Begin and the Decision Design Group, which consisted of the minister of foreign affairs, the IDF Chief of Staff, and the Prime Minister's deputy, on the future agreement in Lebanon.
Prime Minister Begin concluded the meeting by declaring, "we will announce that we will be willing to leave south Lebanon only once our safety is guaranteed" [24].

The next morning, the defense minister, the Chief of Staff, and Minister of Foreign Affairs convened to explore alternatives for a possible agreement.

During the discussion, Chief of Staff Gur said that if the UN Security Council were to pass a resolution ordering the deployment of UN forces in South Lebanon, it would be better for IDF troops to advance towards the Litani River, so that the UN would be deployed there and not close to the Israeli-Lebanese border [24]. Gur's proposal was approved by both ministers [24].

On March 18, the Decision Design Group (DDG) convened and the Chief of Staff presented his plan. The Prime Minister responded with a rhetorical question: "And what other choice do we have? We are defending our home and our children. This is a legitimate war which is well understood by all..." (Gur 1998, 443). Gur interpreted the prime minister's words as approval, and upon returning to his office he ordered the IDF units to begin moving northwards to the Litani River (Gur 1998, 443-44).

On March 19, the UN Security Council adopted UNSC Resolution 425; the resolution called upon Israel to immediately "cease its military action...and withdraw 
forthwith its forces from all Lebanese territory," and announced the establishment of the United Nations Interim Force in Lebanon (UNIFIL).

In spite of the UNSC resolution, the IDF units kept moving northwards, and on March 20 they reached the Litani River, thereby gaining control of all of Southern Lebanon (Evron 2013, 77).

On March 21, Israel declared a unilateral ceasefire, and on March 23 UNIFIL units began their deployment in Lebanon. Israel began to withdraw its troops on April 11, 1978, and the withdrawal was completed on June 13, 1978 (ARR 1978, 225).

\subsubsection{Main Insights}

The decision-making process on Operation Father of Wisdom (Litani) had two main phases.

In the first phase, the decision was made on the dynamics of groupthink-groupthink. The Decision Design Group thought that such a terrorist attack should be met with a "proper" response. The IDF's plan was approved unanimously by the Decision Approval Group. The operation was launched with no decision or definition made with regards to how it was going to end (Henkin 2018, 29).

On March 15, 1978, the first stage of the operation was completed and the Prime Minister stated that IDF forces would remain in South Lebanon until an agreement was reached with "the proper elements" (Henkin 2018, 30).
When it was clear that UN forces were going to deploy in south Lebanon, the IDF chief of staff initiated the next phase of the operation - to continue northwards to the Litani River. On March 18, Lt. Gen. Gur confirmed that Israel has abandoned its original intention of establishing a six-mile security zone and had pushed further north (Keesing's Contemporary Archives 1979).

It was only at the March 19 government (DAG) meeting that the Chief of Staff told the ministers that the IDF units were advancing northwards. As we see, the second stage of the operation was not pre-planned, but a decision made by the Chief of Staff with the approval of the Minister of Defense and the Minister of Foreign Affairs, taking advantage of the IDF's massive presence in South Lebanon.

As we can see most of the decisions were made within the Decision Design Group (DDG) and the most important decision- to advance to the Litani river was designed by two ministers and the IDF's Chief of Staff and approved by the Prime Minister. The Decision Approval Group (DAG) Israel's government didn't have any significant effect on the decisions made, though legally this group has the authority to approve a military operation outside the borders of Israel.

The decision-making process on the second stage of the operation can be described as follows:

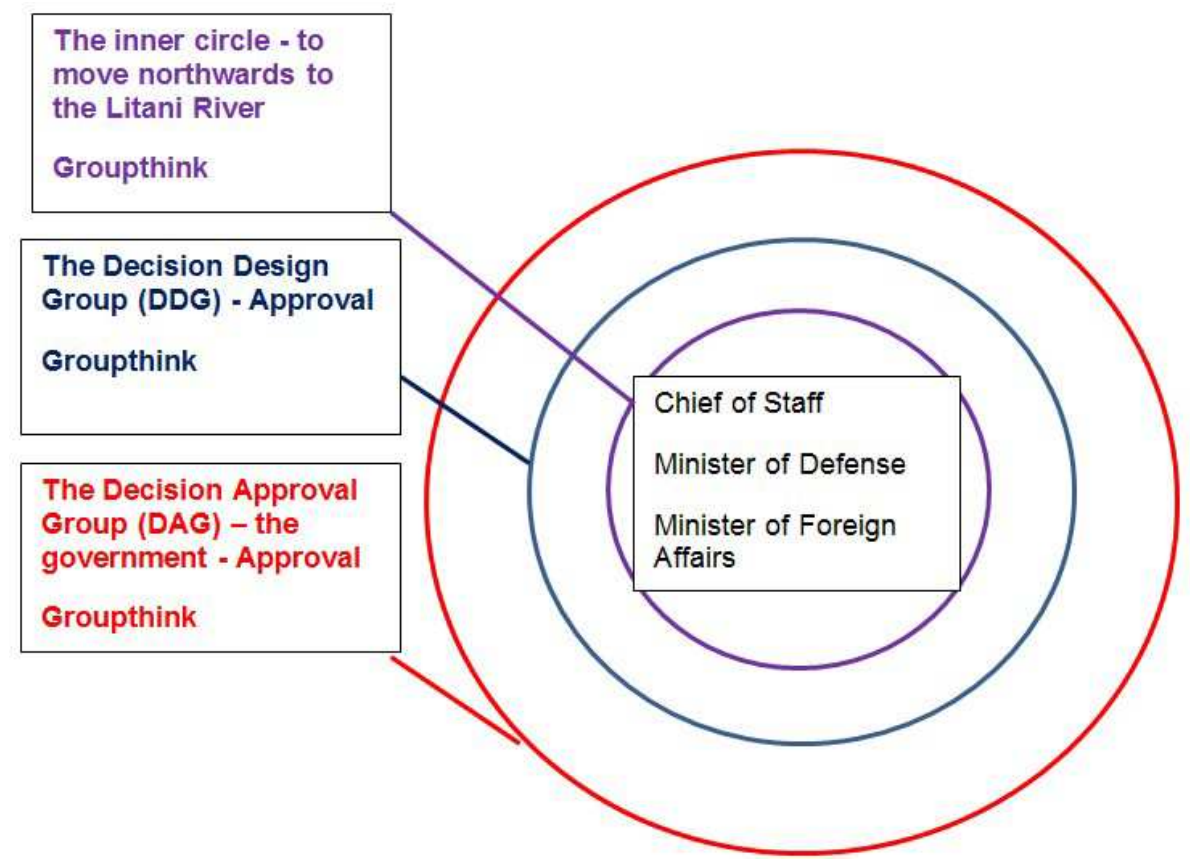

Figure 5. Decision- making process on the second phase of operation "Litani".

\subsubsection{Operation "Defensive Shield" - 2002}

In September 1993, the Oslo Accords were signed between Israel and the Palestinian Authority. Israel withdrew from the large cities in Judea and Samaria and the PA took control of these cities [79].

In September 1996, when Prime Minister Benjamin Netanyahu authorized the opening of one access point to a passage along the Western Wall, the Palestinians protested, and these "tunnel protests" led to almost one hundred Israelis and Palestinian casualties [16].

Based on these confrontations, Israel decided it needed to plan to use massive force to quell Palestinian unrest.

In July 2000, Prime Minister Ehud Barak held negotiations with PA Chairman Yasser Arafat at Camp David in order to try to work out an agreement that would lead to the 
establishment of an independent Palestinian state, but they failed to reach a settlement [6].

On September 28, 2000, the leader of the Israeli opposition, Ariel Sharon, visited the Temple Mount in Jerusalem. This visit was perceived by the Palestinians as a violation of the status quo on the Temple Mount, and it was the trigger for the breakout of the Second Intifada, dubbed by the Palestinians as the "Al Aqsa Intifada" [6]. Unlike the First Intifada, which lasted from 1987 to 1991, this was not a popular uprising, due to the nature of the violence employed by the Palestinians [9, 10]. Suicide bombings were a key weapon used by the Palestinians; during the first two years of the Al-Aqsa Intifada there were 145 suicide bombings, causing many casualties among Israeli citizens [15].

In 2001, elections were held in Israel and Ariel Sharon was elected as Israel's prime minister. He established a coalition with Labor party and other political parties.

Under American pressure, Arafat told his people to hold their fire. In February 2002, serious discussions were held in Israel regarding how to carry on: to get to an agreement, as the American administration tried to broker, or to strike a blow to the Palestinians in order to put an end to the terrorist attacks, as ministers and senior officials within the security establishment claimed [83].

In January 2002 the Palestinians violent attacks were renewed after Israel targeted one of the Palestinian militias (the "Tanzim") leaders. [79].

March 2002 was a particularly bloody month which saw 135 Israeli citizens killed in terrorist attacks. On the evening of March 27, 2002, a Hamas operative blew himself up at a Passover Seder in Netanya's Park Hotel, killing twenty-nine people and wounding sixty-four [2, 39]. That Passover eve, Defense Minister Binyamin Ben Eliezer convened an urgent meeting. There was tremendous frustration in the air. Ben Eliezer opened the meeting by saying that the time had come to strike Hamas with maximum force. IDF Chief of Staff Lt. Gen. Shaul Mofaz and his deputy claimed that it was impossible to wage a successful battle against terrorism without full control over the territories, and that the only way to change the situation was to reoccupy all of the territory under the PA's control, thereby gaining intelligence and operational control, which were essential.

The Chief of Staff proposed that in the first stage it would be necessary to seize control of the centers of terrorism in Gaza, Judea and Samaria, and then remain there and control the area. He claimed that the IDF needed two months to complete its plan. The defense minister approved the idea $[18,79,81]$. The next morning, on March 28, Prime Minister Sharon convened a meeting of the Decision Design Group that included himself, the defense minister, the Chief of Staff and his deputy, the Director of Military Intelligence, the heads of the Mossad and the Shin Bet, the Coordinator of Government Activities in the Territories, and the National Security Advisor [81].

Lt. Gen. Mofaz presented his plan. The prime minister approved a military operation in Judea and Samaria only. A debate took place within the DDG regarding the future of
Chairman Arafat; the Prime Minister was in favor of deporting him out of Israel and was backed by the Chief of Staff and the National Security Advisor. The directors of the intelligence community and the Coordinator of Government Activities in the Territories claimed that such a move would cause huge damage [29].

On the evening of March 28, the cabinet - the Decision Approval Group - convened for about eight hours to discuss the operation. Prime Minister Sharon told the group members, "The Palestinians must be hit, and it must be very painful...We must cause them losses, victims, so they feel a heavy price." (Jewish Virtual Library 2002). The military objective of the operation was to "create a different security reality for Israel". The IDF aimed at gaining security control of the West Bank without the necessity of administering the population [75].

All of the group members supported the operation, though there was a debate about how to handle Arafat; thus, the group's dynamics were of polythink: Prime Minister Sharon wanted to deport Arafat and the Labor party ministers were against this move and threatened to resign if such a decision was taken [81, 29, 84]. After a lengthy discussion, the DAG agreed that Arafat would be defined personally as an "enemy," but that this definition would not apply to the Palestinian Authority as a whole. Accordingly, the cabinet decided to isolate Chairman Arafat "at this stage." The term "isolation" was not clarified during the cabinet's discussion [29].

The government's decision and directive to the IDF cut through the Gordian knot of limitations on IDF activity in the entire area.

The dynamics of the decision-making process on Operation Defensive Shield were mixed. Regarding the need for a military operation, the dynamics were typical of groupthink [62, 79, 8]. The discussion on the future of Chairman Arafat - whether to deport him or "neutralize" him - bore the dynamics of polythink in both groups. Prime Minister Sharon understood that there was a solid objection and was aware of the possible American reaction, so he proposed a compromise: Arafat would be defined as an enemy and would be isolated [82].

Operation Defensive Shield was launched on March 29, 2002. It was the largest military incursion in the West Bank since the 1967 war [44].

One of the first maneuvers of the operation entailed placing a siege on the "Mukataa" (Arafat's compound) in Ramallah, where the PA chairman was at the time [77].

The operation lasted about three weeks, during which time IDF forces re-conquered the major cities in Judea and Samaria, killing about five hundred terrorists and arresting approximately seven thousand people [38]. IDF units also seized massive quantities of weapons and uncovered twentythree explosive laboratories [2].

Operation "Defensive Shield" formally ended on May 10, 2002. On top of the operation's tangible achievements, it also succeeded in restoring the IDF's status: "The idea that Israel is merely a 'paper warrior,' a notion often propagated by individuals such as Hezbollah leader Nasrallah, has been 
shown to be only an illusion" [57].

Insights

The decision-making process during Operation Defensive Shield bore both groupthink and polythink dynamics; both the Decision Design Group and the Decision Approval Group agreed that a military reprisal operation should be launched. Both groups' dynamics were typical of groupthink.
In the discussion in both groups regarding how to deal with Arafat, the dynamics were polythink-polythink. Whereas the prime minister and the IDF chief of staff thought that Arafat should be deported, the heads of the intelligence community and the ministers of the Labor party objected. The proposal was rejected and the decision was taken to isolate Arafat in his compound.

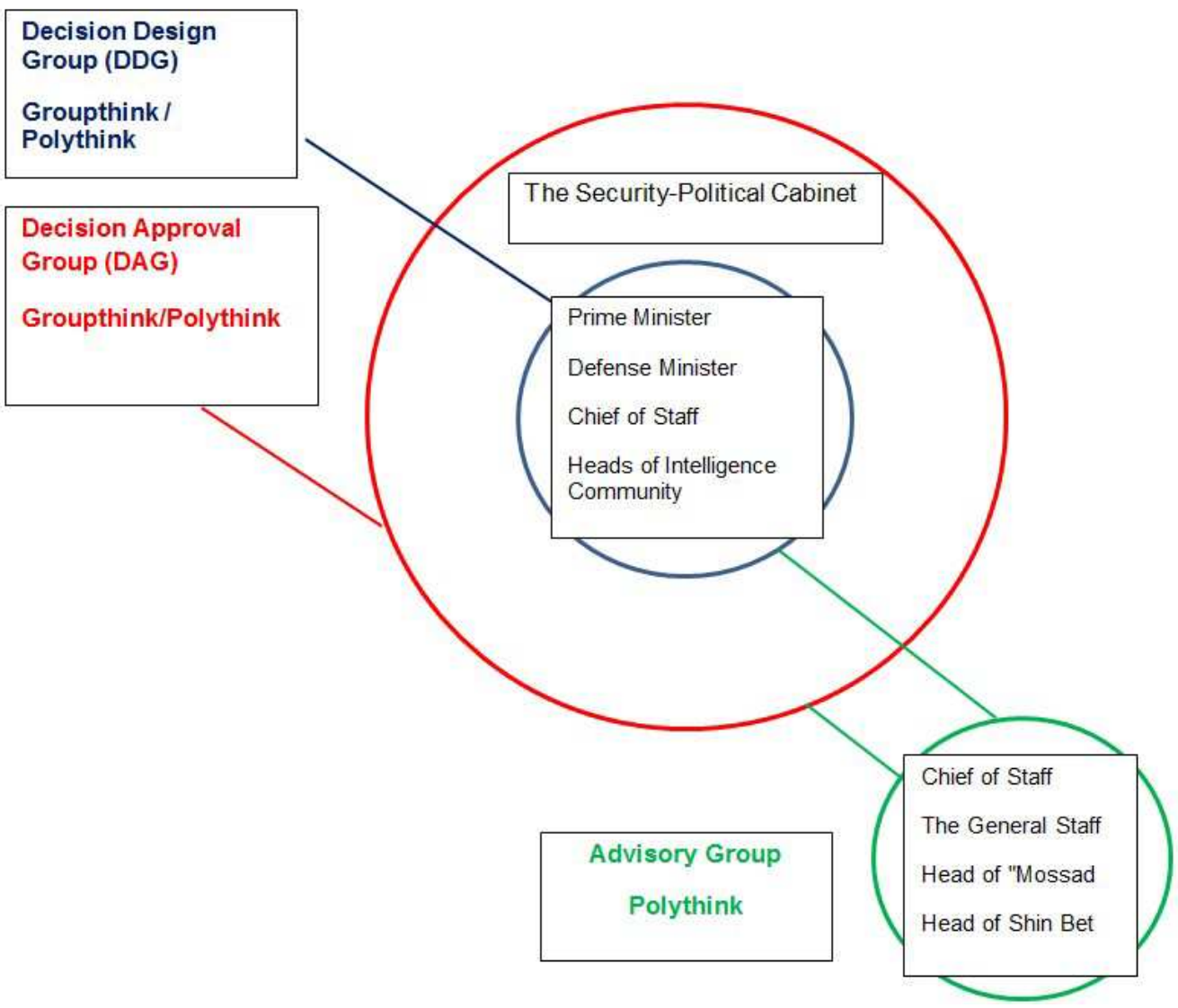

Figure 6. Decision- making on operation Defensive Shield."

\section{Result}

Israel's counter-terrorism policy has been based on the "Dayan Doctrine" regarding reprisal operations and on the "Rabin Doctrine" in cases of abducted civilians or soldiers. The process of decision making on operations in these cases differs from daily decision making, as it is carried out under time pressure and there is a need to immediately decide on how to react. In the case of an abduction of hostages, there is a deadline set by the kidnappers. In the case of a lethal terror attack, Israeli decision makers feel they have to react immediately in order to strike back at the terrorists, make them "pay a price" for their attack, and deter them (and others) from engaging in further terrorist activity against Israel.

\section{Discussion}

In this article, both types of cases were analyzed. In the case of the abduction of Israelis, the discussions were held mainly in the Decision Design Group, which explored the alternatives from surrender to the terrorists demands to a military rescue operation. On both analyzed cases the dynamics of the discussions within this group and within the Decision Approval Group were of polythink as long as there was not a reasonable military option.

When a military operation became feasible, both groups acted on the dynamics of groupthink - they all supported the military operation. In both cases, the same Israeli Prime Minister, Rabin stuck to his principles of not to surrender to terrorist demands and preferred a military rescue operation 
with the great risks involved in such an operation.

Regarding reprisal operations, based on the analysis of the two operations, when a major terror attack occurs, Israeli decision makers feel that they have to react immediately and launch a military operation to hit the terrorists and their infrastructures, deter the terrorists from carrying out further attacks, and prove to the Israeli public and the international community that Israel reacts forcefully when a "red line" is crossed. Therefore, decision makers approve the IDF's recommendations and authorize the military operation.

In both cases, in the main discussions were held in the Decision Design Group (DDG), no other alternatives were explored, since it was clear to the IDF brass and the ministers that the response should be in the form of a military operation.

The operations were launched with no clear definition of how they would end. This was because the Prime minister and the IDF were anxious to react as soon as possible and assumed that they would have time to discuss the concluding stages during the operation. As a result, IDF units (and commanders) operated with a degree of ambiguity, which can sometimes lead to undesirable moves that may have future implications.

Most of the discussions in these cases are held within the Decision Design Group, and it is there that the decision is actually made. In the cases examined here, the dynamics of the group were mostly those of groupthink. When the DDG decides on a military operation, it is approved by the DAG, usually unanimously, since the group's members share the rage and the feeling that "something should be done."

\section{Conclusion}

The four analyzed cases emphasize several important issues:

The dominant role of the leader (Israel's Prime Minister) that designs his preferred course of action and gets the approval of both groups (DDG, DAG).

The decision is actually designed within the Decision Design Group (DDG), it is presented for "formal"approval to the DAG that in most cases unanimously approve the proposed plan.

In the four analyzed cases the dynamics of the discussions held in both groups was of groupthink. In two cases some of the discussions were held in the dynamics of polythink: on the abduction of Israeli passengers to Entebbe, Uganda when there was no reasonable military rescue plan and on the issue of how to deal with PLO's leader, Arafat on operation "Defensive Shield". On the case of Entebbe Prime Minister Rabin convinced the DDG members to begin negotiations with the terrorists and on operation "Defensive Shield" Prime Minister Sharon had compromised on Arafat's issue.

The decision- making process in cases of counter terrorism is short, the time constrains and the ambiguity of the situation doesn't unable the decision- makers to explore various courses of action: in the case of abduction, it's surrender to the terrorist's demands or launch a military rescue operation; in the case of a major terror attack the ultimate decision in Israel is to launch a reprisal operation and the dilemmas are the extent and the duration of that operation.

\section{References}

[1] Allison, Graham T. 1969. "Conceptual Models and the Cuban Missile Crisis." American Political Science Review 63, no. 3: 689-718.

[2] Ahronheim, Anna. 2017. "Remaining Alert: 15 Years After Israel's Biggest West Bank Op Since 1967." The Jerusalem Post, April 29, 2017. https://www.jpost.com/Arab-IsraeliConflict/Remaining-alert-489207.

[3] ARR; Arab Report and Record [1966-1978] no. 6 (March 1631, 1978): 220-226. Stanford University Press. U.S. https://searchworks.Stanford.edu/view3/349402

[4] Ben Dor, Gabriel, Ami Pedatzur, and Badi Hasisi. 2003. "Anti-Liberalism and the Use of Force in Israeli Democracy." Journal of Political and Military Sociology 31, no. 1: 119-142.

[5] Ben Israel, Galit. 2006. "Israeli Government Decision Making in Cases of Hostage - Barricade Terrorism (HBT) Situations and Abductions - Citizens' Rights versus 'The National Good.' Presented at the 20th IPSA World Congress in Fukuoka.

[6] Ben Yishay, Ron. 2012. "Ten Years since Operation Defensive Shield." Facebook, March 20, 2012. Israel. https://www.facebook.com/.../posts/.../34857387517850.

[7] Boin, Arjen, Paul T. Hart, and Sanneke Kuipers. 2007. "The Crisis Approach." In Handbook of Disaster Research, edited by Havidan Rodriguez, Russell R. Dynes, and Enrico L. Quarantelli, 23-35. New York: Springer. U.S.

[8] Black, Ian and Morris, Benny. 1991." Israel's Secret Wars: A History of Israel's Intelligence Services". New York: Grove Press. U.S.

[9] Catignani, Sergio. 2005. "The Security Imperative in Counter Terror Operations: The Israeli Fight against Suicidal Terror." Terrorism and Political Violence 17, no. 1: 245-264.

[10] Cordesman, Anthony H. 2005. "The Israeli-Palestinian War: Escalating to Nowhere". Westport: Praeger Security International. U.S.

[11] David, Saul. 2015. "Operation Thunderbolt: Flight 139 and the Raid on Entebbe Airport, the Most Audacious Hostage Rescue Mission in History". New York: Little Brown and Company. U.S.

[12] Dayan, Moshe. 1955. "Reprisal Actions as a Means for Ensuring Peace." Monthly Review, August 1955. Israel.

[13] Dougherty, James E. and Robert L. Pfaltzgraff. 1990. "Contending Theories of International Relations: A Comprehensive Survey". New York: HarperCollins. U.S.

[14] Drory, Ze'ev. 2005. "Israel's Reprisal Policy, 1953-1956: The Dynamics of Military Retaliation". London: Frank Cass.

[15] Dugan, Laura and Erica Chenoweth. 2012. "Moving Beyond Deterrence: The Effectiveness of Raising the Expected Utility of Abstaining from Terrorism in Israel." American Sociological Review 77, no. 4: 597-624. 
[16] Enderlin, Charles. 2003. "Shattered Dreams: The Failure of the Peace Process in the Middle East, 1995-2002". New York: Other Press. U.S.

[17] Evron, Yair. 2013. "War and Intervention in Lebanon: The Israeli- Syrian Deterrence Dialogue". New York: Routledge. U.S.

[18] Eiland, Giora. 2010. "The IDF and the Second Intifada." Strategic Assessment 13, no. 3: 27-37. www.inss.org.il/he/wpcontent/uploads/sites/2/../(FILE) 128989896504.pdf

[19] Flora, Ed. 1998. "OP Art top the Rescue: Fundamentals for a Hostage Crisis”.

[20] Newport: Naval War College. U.S.

[21] https://www.hsdl.org/?view\&did=450424

[22] Goldstein, Yossi. 2006. "Rabin: A Biography". Tel Aviv: Schocken Publishing House. Israel.

[23] Gilmour, David. 1983. "Lebanon: The Fractured Country". London: St. Martin's Press.

[24] Gur, Motta (Mordechai). 1998. "Chief of the General Staff (1974-1978)". Maarchot Publishing, Tel Aviv. Israel.

[25] Ganor, Boaz. 2005. "The Counter-Terrorism Puzzle: A Guide for Decision Makers". The Interdisciplinary Center Herzliya. Israel.

[26] Ganor, Boaz. 2017. "Israel's Policy in Extortionist Terror Attacks (Abduction and Hostages Barricade Situations)." Perspectives on Terrorism 11, no. 4.

[27] www.terrorismanalyst.com

[28] Gazit, Shlomo. 2016. "At Key Points of Time". Tel Aviv: Miskal-Yedioth Ahronoth Books and Chemed Books. Israel.

[29] Harel, Amos and Avi Issacharoff. 2004. "The Seventh War: How We Won and Why We Lost the War with the Palestinians". Tel Aviv: Miskal-Yedioth Ahronoth Books and Chemed Books. Israel.

[30] Hart, Paul T., Eric K. Stern, and Bengt Sundelius, editors. 1997. "Beyond Groupthink: Political Group Dynamics and Foreign Policy Making". Ann Arbor: University of Michigan Press. U.S.

[31] Henkin, Yagil. 2018. "A High Price for our Blood: Israel's Security Doctrines." The Jerusalem Institute for Strategy and Security. Israel.

[32] https://jiss.org/en/henkin-high-price-blood-israel's-securitydoctrine

[33] Hermann, Margaret G. and Charles F. Hermann. 1998. "Hostage Taking, the Presidency and Stress." In Origins of Terrorism: Psychologies, Ideologies, Theologies, States of Mind, edited by Walter Reich, 208-220. Washington: The Woodrow Wilson Center Press. U.S.

[34] Herzog, Chaim. 1996. "The War Against Terrorism: Entebbe." In: From Troy to Entebbe: Special Operations in Ancient and Modern Times, edited by John Arquilla. Lanham: University Press of America. U.S

[35] Historical Security Council Research Report. 2014. "The Situation Between Israel-Lebanon.” Model United Nations International School of the Hague. http://www.munish.nl/pages/downloader?code=hsc01\&comco $\mathrm{de}=$ hsc\&year $=2014$

[36] Hudson, Valerie M. 2014. "Foreign Policy Analysis: Classic and Contemporary Theory". Lanham: Rowman \& Littlefield. U.S.

[37] Hughes, Geraint. 2011. "The Military's Role in Counterterrorism: Examples and Implications for Liberal Democracies". Carlisle: Strategic Studies Institute, U.S. Army War College.

[38] Inbar, Efraim and Eitan Shamir. 2014. "Mowing the Grass: Israel's Strategy for Protracted Intractable Conflict." Journal of Strategic Studies 37, no. 1: 65-90.

[39] Jaeger, David A. and Daniele M Paserman. 2005. "The Cycle of Violence? An Empirical Analysis of Fatalities in the Palestinian- Israeli Conflict." IZA Discussion Paper 1808. IZA, Bonn, Germany. http://ftp.iza.org/dp1808.pdf.

[40] Janis, Irving L. 1982. "Groupthink: Psychological Studies of Policy Decisions and Fiascoes" (2nd edition). Boston: Houghton Mifflin. U.S.

[41] Jewish Virtual Library. 2002. "Israel's Wars and Operations: Operation Defensive Shield (March 22-April 21, 2002)". https://www.jewishvirtuallibrary.org/operation-defensive-shield.

[42] Kahl, Colin. 2007. "COIN of the Realm." Foreign Affairs 86, no. 6: 466-474.

[43] Kahneman, Daniel and Amos Tversky. 1979. "Prospect Theory: An Analysis of Decision Under Risk." Econometrica 47, no. 2: 232-279.

[44] Katz, Samuel. 2016. "The Ghost Warriors: Inside Israel's Undercover War against Suicide Terrorism". New York: Penguin Random House. U.S.

[45] Kegley, Charles W. and Eugene R. Wittkopf, 2005. World Politics: Trends and Transformation. Belmont: Thomson Wadsworth. U.S.

[46] Keesing's Records of World Events. 1976. "Hijacking of Air France Airbus by Followers of Popular Front for the Liberation of Palestine - Israeli Action to Liberate Hostages Held at Entebbe Airport." Vol. 22, August 1976. http://web.stanford.edu/group/tomzgroup/pmwiki/uploads/137 7-1976-08-KS-a-RCW.pdf

[47] Keesing's Contemporary Archives. 1978. "Israeli Invasion of Southern Lebanon March 1978- Deployment of UN Peace Keeping Force - Israeli Withdrawal.” Vol. 25, June 1979.

[48] Lemke, Douglas and Patrick M. Regan. 2004. "Interventions as Influence." In The Scourge of War: New Extensions on an Old Problem, edited by Paul F. Diehl, 145-68. Ann Arbor: University of Michigan Press. U.S.

[49] Levitt, Mathew. 2008."Negotiating Under Fire: Preserving Peace Talks in the Face of Terror Attacks". Rowman and Littlefield, Maryland, U.S.

[50] Levy, Jack S. 1992. "An Introduction to Prospect Theory." Political Psychology 13, No. 2: 171-186.

[51] Maoz, Zeev. 1990. "National Choices and International Processes". Cambridge: Cambridge University Press. U.S.

[52] Maoz, Zeev. 1981. "The Decision to Raid Entebbe: Decision Analysis Applied to Crisis Behavior." Journal Of Conflict Resolution 25, no. 4: 677-707. 
[53] Mintz, Alex. 2004. "How Leaders Make Decisions: A Poliheuristic Perspective". Journal of Conflict Resolution 48, no. $1: 3-13$.

[54] Mintz, Alex and Karl DeRouen, Jr. 2010. "Understanding Foreign Policy Decision-Making". New York: Cambridge University Press. U.S.

[55] Mintz, Alex, and Geva, Nehemia. 1997. "The Poliheuristic Theory of Foreign Policy Decision-Making." In Decisionmaking on War and Peace: The Cognitive-Rational Debate, edited by Nehemia Geva and Alex Mintz, 81-101. Boulder, CO: Lynne Rienner. U.S.

[56] Mintz, Alex and Wayne, Carly. 2016. "The Polythink Syndrome: U.S Foreign Policy Decisions on 9/11, Afghanistan, Iraq, Iran, Syria and ISIS". Stanford: Stanford University Press. U.S.

[57] Mofaz, Shaul. 2002. "Operation Defensive Shield: Lessons and Aftermath." Policy \#387. June 18, 2002. The Washington Institute. https://www.washingtoninstitute.org/policyanalysis/view/operation-defensive-shield-lessons-andaftermath

[58] Moyer, Mark. 2009. "A Question of Command: COIN from Civil War to Iraq". New Haven: Yale University Press. U.S.

[59] Payne, John W., James R. Bettman, and Eric J. Johnson. 1998. "Adaptive Strategy Selection in Decision Making." Journal of Experimental Psychology: Learning, Memory, and Cognition 14 (July): 534-552.

[60] Peres, Shimon. 2017. "No Room for Small Dreams". MiskalYedioth Ahronoth Books and Chemed Books. Israel.

[61] Pedhazur, Ami and Cassy Dorff. 2009. "The Inverse Effects of Military Innovations.” APSA 2009 Toronto Meeting Paper.

[62] Peri, Yoram. 2002."The Israeli Military and Israel's Palestinian Policy: From Oslo to Al Aqsa Intifada". United States Institute for Peace. Peace works no. 47.www.usip.org/sites/default/files/pwks47.pdf

[63] Quainton, Anthony C. E. 1985. "Terrorism: Policy, Action and Reaction." In Perspectives in Terrorism, edited by Lawrence Zelic Freedman and Yonah Alexander. Wilmington, DE: Scholarly Resources. U.S.

[64] Rabin, Yitzhak and Dov Goldstein. 1979. "Service Notebook". Tel Aviv: Ma'ariv Library. Israel.

[65] Regan, Patrick M. 2002. "Civil Wars and Foreign Powers: Outside Intervention in Intrastate Conflict". Ann Arbor: University of Michigan Press. U.S.

[66] Renshon, Jonathan and Stanley A. Renshon. 2008. "The Theory and Practice of Foreign Policy Decision Making." International Society of Political Psychology 29, no 4: 509536.

[67] Robinson, J. A. and Richard C. Snyder. 1965. "Decision Making in International Politics." In International Behavior: A Social-Psychological Analysis, edited by Herbert C. Kelman. New York: Holt, Rinehart and Winston. U.S.
[68] Rosati, Jerel A. and James M. Scott. 1993. "The Politics of United States Foreign Policy". Orlando: Harcourt Brace Jovanovich. U.S.

[69] Rosenthal, Uriel, Michael T. Charles, and Paul T. Hart, editors. 1989. "Coping with Crises: The Management of Disasters, Riots and Terrorism". Springfield: Charles C. Thomas. U.S.

[70] Sofrin, Amnon. 2019. "A Two-Group Decision Making Model on Military Intervention." Ph.D. dissertation, Hebrew University of Jerusalem. Israel.

[71] St. John, Peter. 1991. "Counterterrorism Policy Making: The Case of Aircraft Hijacking 1968-1988." In Democratic Responses to International Terrorism, edited by David Charters, 75. New York: Transnational Publishers. U.S.

[72] Tversky, Amos and Daniel Kahneman. 1981. "The Framing of Decisions and the Psychology of Choice." Science, New Series 211, no. 4481: 453-458.

[73] Trumbore, Peter F. and Mark A. Boyer. 2000. "International Crisis Decision Making as a Two-Level Process." Journal of Peace Research 37, no. 6: 679-697.

[74] Williamson, Tony. 1976. "Counterstrike Entebbe". London: Harper Collins.

[75] Ya'alon, Moshe. 2008. "The Long Short Road". Tel Aviv: Miskal-Yedioth Ahronoth Books and Chemed Books. Israel.

[76] Yatom, Danny. 2009. "The Confidant: From Sayeret Matkal to the Mossad". Tel Aviv: Miskal-Yedioth Ahronoth Books and Chemed Books. Israel.

[77] Ynet. 2009. "Operation Defensive Shield (2002)." https://www.ynetnews.com/articleInterviews

[78] Eran, Amos. Former Director-General of the Prime Minister's Office. 2019.

[79] Major General (ret.) Eiland, Giora. Former Head of the Israel Defense Forces Planning Branch. 2019.

[80] Major General (ret.) Gazit, Shlomo. Former Director of IDF Military Intelligence. 2019.

[81] Brigadier-General (ret.) Herzog, Michael. Former Military Secretary to the Defense Minister. 2019.

[82] Major General (ret.) Kaplinsky, Moshe. Former Military Secretary to the Prime Minister. 2019.

[83] Brigadier-General (ret.) Kuperwasser, Joseph. Head of the Analysis and Production Division of IDF Military Intelligence. 2019.

[84] Major General (ret.) Vilnai, Matan. Former Minister of Science, Culture and Sport. 2019.

[85] Major General (ret.) Yatom, Danny. Former Military Secretary to the Prime Minister. 2018.

[86] Rubinstein, Amnon. Former Minister of Education. 2019. 